\title{
The Economic Impact of Credit Guarantees in Jordan
}

\author{
Reham Abu-baker*, Mohammad Adeinat \\ Department of Business Economics, School of Business, University of Jordan, Amman, Jordan \\ Email address: \\ Reham.baker82@gmail.com (R. Abu-baker),mk.adeinat@gmail.com (M. Adeinat) \\ ${ }^{*}$ Corresponding author
}

\section{To cite this article:}

Reham Abu-baker, Mohammad Adeinat. The Economic Impact of Credit Guarantees in Jordan. International Journal of Business and Economics Research. Vol. 9, No. 5, 2020, pp. 288-297. doi: 10.11648/j.ijber.20200905.11

Received: July 30, 2020; Accepted: August 13, 2020; Published: August 25, 2020

\begin{abstract}
Credit guarantee schemes have become a popular instrument to increase access to credit for financially constrained firms, typically small and medium-sized enterprises (SMEs). This government intervention of using credit guarantees as techniques for increasing access to finance for certain borrowers is argued to be useful, but their success and sustainability depend on many factors. Since 1994, the Jordan loan guarantee corporation through its several programs aims to support SMEs and enable them to have access to finance at a reasonable cost. This paper provides an evaluation analysis and impact assessment of credit guarantee system in Jordan by focusing on the Jordanian loan guarantee corporation (JLGC) performance. It found a positive impact on the Jordanian economy, but more emphasis on the guarantee system is needed with cooperation between all parties of the banking system, Central bank, and JLGC to achieve policy goals. Also it examines the government's recent initiative in the National Program for Finance and Loan Guarantee to encounter Corona crisis and found that it enhances the positive impact on the economy. In addition, more deep assessments that consider financial sustainability and economic additionally will be fruitful, as well as an assessment of credit guarantees against alternative policy instruments.
\end{abstract}

Keywords: SMEs, Credit Guarantees, Public Guarantees, SME Financing, Access to Finance, JLGC

\section{Introduction}

This fact is widely known that small and medium enterprises (SMEs) play a significant role in most economies through their contribution in employment creation, growth and development $[1,2]$, they are seen as the engines of growth, and this role is specifically crucial in the developing countries [3, 4]. However, this kind of firms (SMEs) are generally hampered by several obstacles most important is credit constraint and lack of access to bank loans $[5,6]$.

Small and medium enterprises often cannot get access to banks loans due to lack of collaterals, managerial experience, and credit history with the banks. Also, private financial intermediaries may lack incentives to bear the upfront costs of learning about new borrowers and inferring required lending techniques, once their efforts demonstrate that others can easily reproduce them [7].

Therefore, to support SMEs and enable them to have access to credit, most countries use credit guarantee schemes as a policy instrument to enhance growth [8, 9]. Credit guarantee schemes are tools in which a third party-the guarantor-undertakes to pledge to repay part or amount of the loan in full to the lender if the borrower fails to repay. In order to enable firms to obtain credit or improve the terms and conditions under which borrowing can take place, the guarantor must bear part or all of the credit risk, which reduces the risk that the bank may face. So this tool can help to overcome market failure regarding resource allocation. However, these interventions usually have inherent costs like crowding out alternative financing sources or giving funds to firms that fail to use them productively and creating contingent fiscal liabilities.

This paper focuses on the schemes of guarantee role and performance in Jordan. The Jordanian loan guarantee corporation was founded in 1994 as a public limited liability company to provide guarantee service to SMEs and productive projects by offering collateral for loan risks granted by banks. It is $48 \%$ majority-owned by the central bank of Jordan, which is $100 \%$ owned by the government. In this paper, we will emphasize on evaluating the impact of JLGC schemes on the economy. 


\section{Literature Review}

In spite of the fact that the effect of banking credit on SMEs has been broadly studied, credit guarantee has maybe received much less attention [10], this is mainly due to lack of data.

Levitsky and Parasad in 1989 studied credit guarantee across 27 developed and developing countries; they studied the operational models of credit guarantee systems and also evaluated some of them according to building trust and granting [11]. The effects of credit guarantee on SMEs and the economies are huge. They boost lending to firms, thus enhance access to finance [12]. Also, credit guarantee helps SMEs to minimize their costs of borrowing [13]. In addition, it ensures new business formation, development and growth [14].

According to Bookwork \& Sharif 2005, credit guarantee induce lenders by providing collateral as compensation in case the loan is not repaid. In other words, it allows them to transfer the risk of loan recovery to the guarantor [12]. These incentives help banks and financial institutions to overcome the problem of information asymmetry [15]. Therefore, policymakers use credit guarantee as an instrument to promote welfare, stability, foster economic growth and decrease unemployment levels [16] besides increasing exports [17]. Also, credit guarantees help through creating more jobs [18] and reduce poverty [14]. Furthermore, credit guarantees affect sectors contribution in GDP as [19] noted that the sub-sector that experienced poor financing from credit guarantee fund had very low contribution in the domestic product in Nigeria. [20] Established a positive and significant effect of the amount funded to specific subsectors on output growth in them.

By the early 2000s, credit guarantee schemes became prevalent worldwide with more than 2,250 credit guarantee schemes of various types operating in more than 70 countries [21]. Since the 1950s, Governments have established the public credit guarantee schemes targeting a sector, region, or type of company (such as a small and medium-sized enterprise) that considered underserved by banks and/or whose growth is believed to have positive externalities [22]. Over the past few decades, public credit guarantee schemes have become increasingly popular among governments and have become widespread in both developed and developing countries. Also, all multilateral development banks operate in some form of the credit guarantee system [23].

In his study, Shim [24] used the ratio of outstanding credit guarantees to GDP to assess the effects of credit guarantees in Asian countries. It was over 5\% for Japan and Korea for the period 2001-2005. OECD study in 2013 [8] stated that credit guarantee reaches a considerable ratio of GDP. The highest rate of outstanding guarantees to GDP amongst the European region was in Italy $(2.2 \%)$ while in Asia the highest was in Japan (7.3\%) and Korea (6.2\%). In addition, the European Association of Mutual Guarantee Societies (ACEM) in 2013 used ratio of credit guarantees outstanding to GDP to evaluate the impact of credit guarantees on the member national economies. Dang Binh [25] also used this methodology to assess impact of credit guarantee system in Hungary.

\section{Methodology}

In this paper, after reviewing the literature on both economic roles for small and medium enterprises and public credit guarantees, we focus on Jordan loan Guarantee Corporation, its programs, performance, and impact on the economy. We studied its operational model; its programs followed by the result of operations from 2007 to 2019. We studied the trend in numbers and volumes of yearly approved guarantees and outstanding guarantees, then calculated yearly ratios of new activity and profits to outstanding guarantees and examined the trend of both ratios. We calculated the outstanding guarantees to GDP ratios, then conducted comparisons with some regional indicators, to conclude with the impact on SMEs and economy. In the last section, we reviewed the 2020 government national finance and guarantee program that was launched to encounter Corona crisis and stimulus the economy. Detailed data were used from many sources like JLGC reports, Central Bank of Jordan Statistics, the European Association of Mutual Guarantee Societies (AECM) reports and Jordan Department of Statistics. It was very helpful to get the opportunity to interview the Director-General of JLGC to get a deeper understanding of its operations.

\section{Small and Medium Enterprises}

\subsection{Definition of Small and Medium Enterprises}

According to the International Labor Organization (ILO), small companies have less than 10 workers, while medium enterprises are those that employ between 10 and 99 workers, and more than 99 are considered large companies.

In 2011, the Central Bank of Jordan (CBJ) established a definition for SMEs stating that for a firm to be considered an SME, it must not be a public company, insurance company or financial institution and small companies are those in which the volume of assets is less than million Dinars or its annual revenue is less than million Dinars, and it employs 5 to 20 employees. Medium enterprises are those whose assets values are between one and 3 million dinars, or their annual revenues are between 1 and 3 million Dinars, and they employ 21 to 100 employees.

It is worth noting that after the COVID-19 crisis, the CBJ has redefined SMEs by expanding the definition so that companies with assets value less than 5 million dinars or annual revenues not exceeding 5 million Dinars, and the number of workers must not be more than 200, are considered SMEs and can benefit from the stimulus packages directed to the SMEs sector. This indicates that the Jordanian government believes in the importance of supporting SMEs and their need to get greater access to finance.

\subsection{Small and Medium Enterprises in Jordan}

The SMEs are having a vital function in the economy of each country due to their roles in socio-economic development. SMEs are considered the supporting source of 
GDP by providing employment opportunities and also supporting large enterprises by providing raw materials and intermediate inputs for industries and other productive activities. SMEs usually have the adaptation ability to market conditions, innovations, and any changes in markets or customer's preferences.

In Jordan, it is possible to provide effective solutions to confront poverty and unemployment in Jordan through small and medium companies [26]. SMEs -according to USAID and the overseas private investment corporation 2019 statistics-contribute up to $50 \%$ of the GDP and provide between 40 and 60 percent of private-sector jobs. Besides that, they engage in around $30 \%$ of exports. However, their share of banking credits to the private sector is only about $9.8 \%$ which indicates they face difficulties in accessing bank loans. Thus, they need support to increase their access to finance from banking institutions.

Recently, the Central Bank of Jordan (CBJ) in cooperation with Jordan loan guarantee corporation JLGC provided many programs to induce SMEs ability to get needed finance, to grow, and to contribute more to the economy. One of these programs is credit guarantee service.

Figure 1 shows the trend of the ratio of credit to SMEs to total credit to the private sector over the last sixteen quarter.

Table 1. Numbers of SMEs in Jordan in 2011 and 2018.

\begin{tabular}{llll}
\hline \multirow{2}{*}{ Firms type } & $\mathbf{2 0 1 1}$ & & $\mathbf{2 0 1 8}$ \\
\cline { 2 - 4 } & Number of firms & Share of total firms \% & Number of firms \\
\hline Micro & 130517 & $88.6 \%$ & 150338 \\
Small & 13519 & $9.2 \%$ & 13485 \\
Medium & 2407 & $1.6 \%$ & 2815 \\
S\&M & 15926 & $10.8 \%$ & 16300 \\
Large & 730 & $0.5 \%$ & 881 \\
Total & 147173 & $100 \%$ & 167519 \\
Firms type & 2011 & 2018 & \\
\hline
\end{tabular}

*source: The Economic and Social Council and Jordan statistic department.

Table 2. SMEs banking credit to total credit to the private sector: (in millions).

\begin{tabular}{|c|c|c|c|c|}
\hline As of the end of & Credit to small firms & Credit to medium size firms & Credit to SMEs $(1+2)$ & Credit to SMEs/ total credit to the private sector \\
\hline Mar 2016 & 518.2 & 1235.6 & 1753.8 & $9.3 \%$ \\
\hline Jun 2016 & 533.4 & 1298.1 & 1831.5 & $9.4 \%$ \\
\hline Sep 2016 & 510.3 & 1331.0 & 1841.3 & $9.3 \%$ \\
\hline Dec 2016 & 518.0 & 1465.9 & 1983.9 & $9.8 \%$ \\
\hline Mar 2017 & 592.1 & 1450.1 & 2042.2 & $9.8 \%$ \\
\hline Jun 2017 & 588.3 & 1620.1 & 2208.4 & $10.4 \%$ \\
\hline Sep 2017 & 590.2 & 1519.9 & 2110.1 & $9.7 \%$ \\
\hline Mar 2018 & 647.2 & 1584.8 & 2232.0 & $9.9 \%$ \\
\hline Jun 2018 & 655.1 & 1637.0 & 2292.1 & $10.0 \%$ \\
\hline Sep 2018 & 676.0 & 1660.3 & 2336.3 & $10.1 \%$ \\
\hline Dec 2018 & 702.5 & 1628.8 & 2331.3 & $10.0 \%$ \\
\hline Mar 2019 & 870.2 & 1498.1 & 2368.3 & $10.1 \%$ \\
\hline Jun 2019 & 708.9 & 1690.1 & 2399.0 & $10.0 \%$ \\
\hline Sep 2019 & 715.8 & 1685.5 & 2401.3 & $10.0 \%$ \\
\hline
\end{tabular}

*source: The central bank of Jordan.

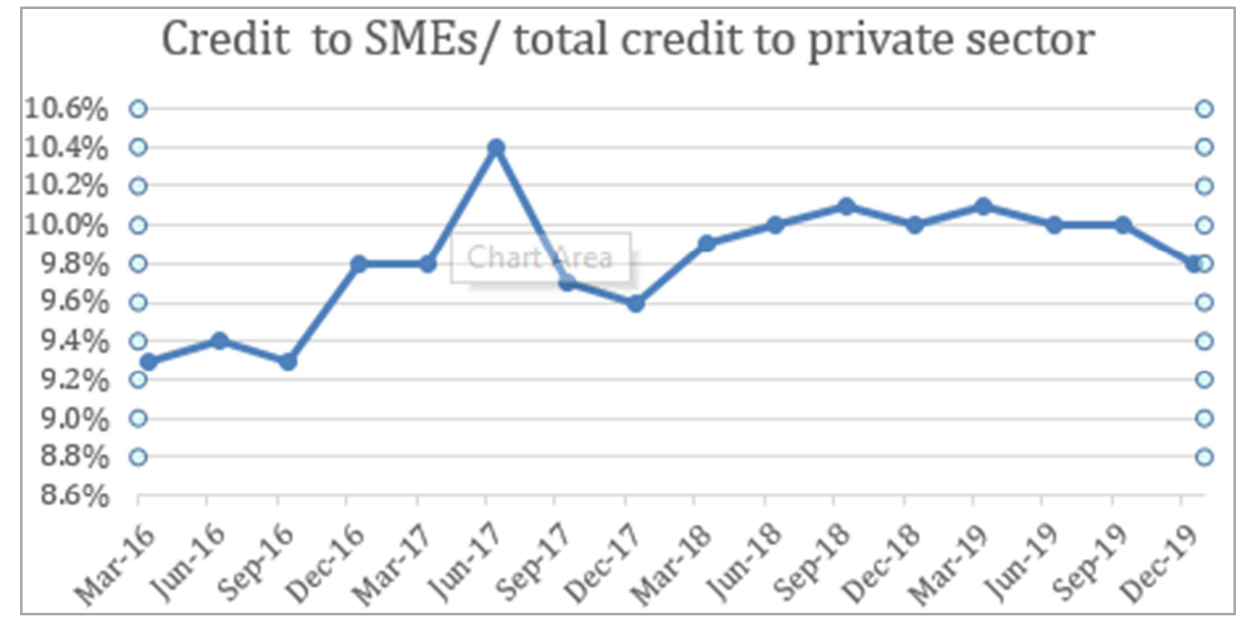

Figure 1. Ratio of credit to SMEs to total credit to the private sector 


\section{Public Credit Guarantee Schemes}

\subsection{The Rationale Behind Credit Guarantee}

1-Improve access to credit and/or lower borrowing costs for certain borrowers. 2-Guarantors might be able to spread risks by providing guarantees to several lenders, thus improving risk diversification.

\subsection{Public Credit Guarantee Schemes Around the World}

Credit guarantee schemes have existed in various forms since the nineteenth century. Some of the earliest credit guarantee schemes in Europe were mutual credit guarantee associations that developed from guild or craft organizations. In 1915 in Holland, the first public credit guarantee scheme was founded. In 1937 in Tokyo, Japan established a regional government-run credit guarantee scheme, and in the 1940s, schemes starting their operations in other regions of Japan. In the 1950s a group of other countries developed public credit guarantee schemes. Nevertheless, most government-managed credit guarantee schemes were established in the 1990s and 2000s [19].

There are now more than 70 credit guarantee schemes around the world. Some have been working for 80 years while some are relatively new. For example in the United States of America, it started in 1953 through the small business administration (SBA). The size of public credit guarantee schemes varies in regard to the volume of loans guaranteed between countries. Asia has some of the most significant public credit guarantee schemes. The Japanese credit guarantee system is considered as the largest in the world in terms of the volume of guarantees. With about 730,000 new loans guaranteed in 2013 and a stock outstanding of 3.1 million guarantees, totaling about 305 billion U. S. dollars. The second-largest scheme is in South Korea, with a stock of more than 400,000 outstanding guarantees in 2013, totaling about 40 billion US Dollars, almost four percent of the South Korean GDP.

\subsection{Credit Guarantee System in Jordan}

In Jordan, the credit guarantee system is operated mainly by one organization: the Jordan loan Guarantee Corporation (JLGC), it provides guarantee service for a wide range of business sectors. It is $48 \%$ majority-owned by the central bank of Jordan, which is $100 \%$ owned by the government.

Table 3. JLGC main characteristics

\begin{tabular}{ll}
\hline Establishment & 1994 \\
\hline Target enterprises & Small and medium enterprises, start-ups. \\
Major businesses & The vast range of sectors or economic activities. i.e., manufacturing, commercial, telecommunication, services. \\
Source of funds & The Central Bank of Jordan, financial institution are the main shareholders \\
\hline
\end{tabular}

\subsubsection{JLGC Operational Model and Programs}

Around the world, public credit guarantee schemes vary in their design, particularly in their operating rules, management structure, and the characteristics of their guarantees, like the coverage ratio and pricing. These design choices can be critical for the success and financial sustainability of credit guarantee schemes because they influence the participation of financial institutions, administrative costs, and loan default rates.

The process of credit guarantee through JLGC starts from the bank's loan application with all relevant details about the borrower enterprise. The Loan Guarantee Company provides full information on the potential borrowers in order to assess the creditworthiness and risk. This includes inquiries about the cases mentioned in the daily newspapers for nearly twenty years, inquiring about the issues that concern the state treasury "tax and customs issues", and inquiries from the Ministry of Justice's database.

JLGC adopts the principle of participation in making credit decisions, through either preparing pre-agreed terms of reference with the banks, or through the basic determinants that require the banks to prepare a credit study that shows the project's data, income statement and the financial status of the project, a statement of the customer's account and these data are presented to the company to participate in the evaluation and expressing an opinion from the reality of experience in dealing with this sector (as the principle of participation in decision-making improves the quality of financing). There are some programs in which checklist conditions are prepared as a basis in providing the basic requirements for financing and reducing risks.

If the application is approved, the bank must pay a guarantee commission that ranges from $0.75 \%$ to $1.5 \%$. It is agreed to set a time frame for the implementation of the project and for the loan, which contributes to monitoring and improves the quality of credit. Then documenting contracts and guarantees in accordance with a sound legal basis. Continuous follow-up procedures and credit control measures which are consistent with the instructions of the Central Bank and the participating bank should be done. Repayments are made to the bank under the loan conditions.

In a case where the borrower does not repay all or part of the loan, JLGC guarantees the risk of default by the borrower or project with a ratio do not exceeding $70 \%$ plus 6-months interest and according to the applicable guarantee program. Where it pays the amount of compensation to the bank, the amount paid is deposited as a trust account (which reduces the risk) considering this amount as insurance cash to mitigate the risk of credit by minimizing required provisions for non-performing loans. The bank proceeds with legal procedures to collect repayments from the borrower; any payments collected will be returned to JLGC according to their coverage ratio. 
Table 4. JLGC main programs and products.

\begin{tabular}{|c|c|c|c|c|}
\hline Product & Type of customers & $\begin{array}{l}\text { Coverage } \\
\text { ratio }\end{array}$ & $\begin{array}{l}\text { Max. payment } \\
\text { period (month) }\end{array}$ & $\begin{array}{l}\text { Max. loan } \\
\text { amount (JOD) }\end{array}$ \\
\hline SMEs loans guarantee. & $\begin{array}{l}\text { Small and medium-sized enterprises from all fields in the private } \\
\text { sector. }\end{array}$ & $70 \%$ & 72 & 250,000 \\
\hline Industrial finance guarantee (Ejada). & SMEs in industrial and services sectors & $70 \%$ & 96 & $1,000,000$ \\
\hline Leasing guarantee (Ejada). & SMEs in all sectors except the agricultural and financial sectors. & $70 \%$ & 96 & $1,000,000$ \\
\hline Kafala Islamic finance. & SMEs and startups. & $70 \%$ & 96 & $1,000,000$ \\
\hline Renewable energy program. & $\begin{array}{l}\text { Companies that desire to finance a renewable energy system that } \\
\text { conforms to JREEEF. }\end{array}$ & $\begin{array}{l}\text { Up to } \\
100 \%\end{array}$ & 60 & 500,000 \\
\hline Real estate loans guarantee. & Individuals. & $75 \%$ & 300 & 75,000 \\
\hline Land purchase guarantees. & Individuals. & $70 \%$ & 120 & 50,000 \\
\hline Exports guarantees. & Exporters. & $90 \%$ & 6 & $7,500,000$ \\
\hline Domestic sales credit guarantee. & Firms in commercial and trading sectors. & $80-90 \%$ & $4-6$ & $4,000,000$ \\
\hline SMEs loans guarantee. & $\begin{array}{l}\text { Small and medium-sized enterprises from all fields in the private } \\
\text { sector. }\end{array}$ & $70 \%$ & 72 & 250,000 \\
\hline Industrial finance guarantee (Ejada). & SMEs in industrial and services sectors & $70 \%$ & 96 & $1,000,000$ \\
\hline Leasing guarantee (Ejada). & SMEs in all sectors except the agricultural and financial sectors. & $70 \%$ & 96 & $1,000,000$ \\
\hline
\end{tabular}

\subsubsection{Consequences of Credit Guarantee Activities and Their Effect on the Economy}

Firstly, results of operations of JLGC are assessed based on two factors; outstanding guarantees and guarantees approved during the year. At the end of the year 2018, JLGC had achieved outstanding guarantees of 4,972 cases with a total value of 109 million JD. Moreover, guarantees approved were 3,020 cases with a total value of 141.9 million JD. Both indicators are increasing in value and numbers.

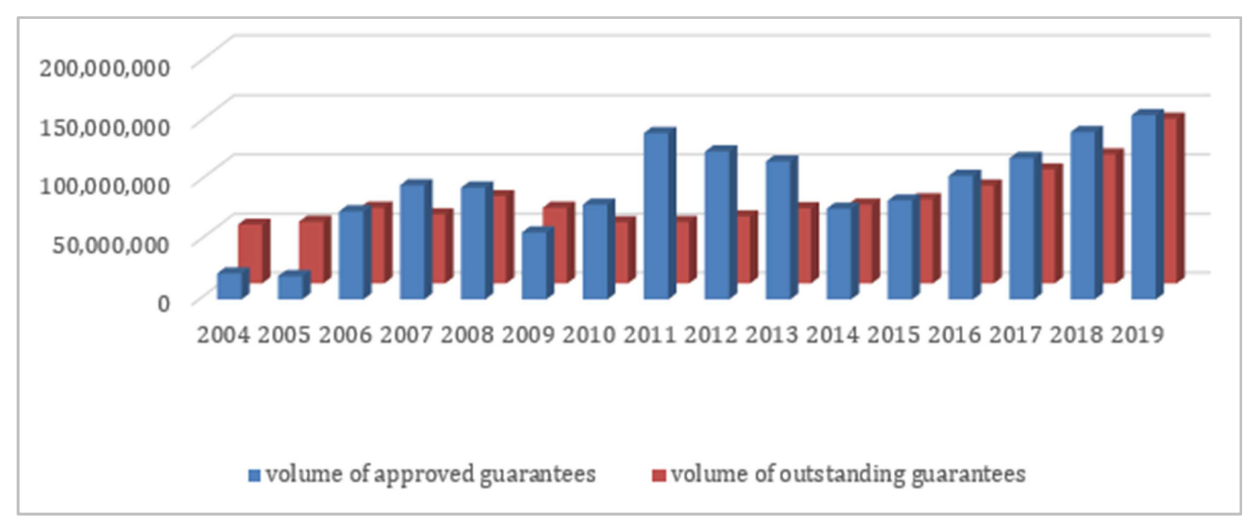

Figure 2. The volume of yearly approved and outstanding guarantees.

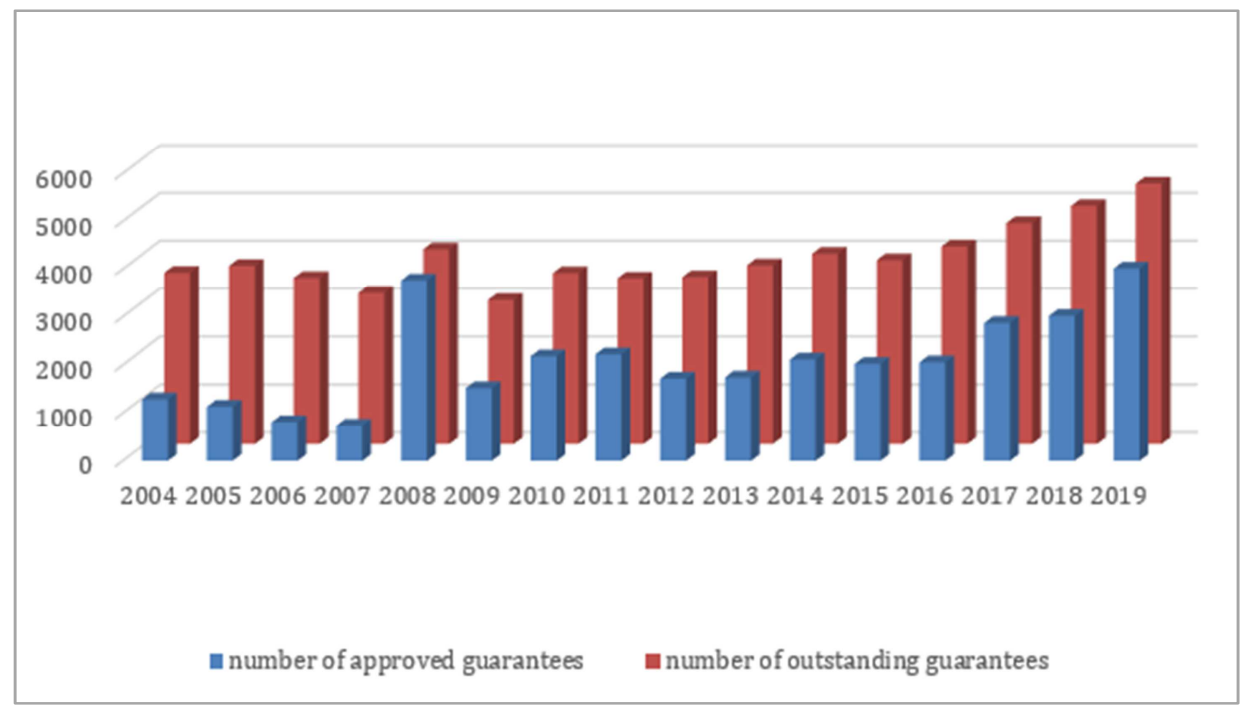

Figure 3. Number of yearly approved and outstanding guarantees. 
It seems that JLGC has a vital role in capital reallocation and increasing firms' access to finance from the banks, which help them to survive, develop and grow. We can note in figures 2 and 3 that JLGC outstanding guarantees are increasing in both numbers and volume-a slight decrease in years following the financial crisis 2009 and 2010 then the indicator tends to increase again-and it helped to stabilize after crisis period. The jump or growth noticed in 2011 and 2012 concur with the release of the Central Bank and JLGC special programs to motivate SME lending.

Figure 3 shows the numbers of guarantees approved and outstanding for the last fifteen years, and they tended to increase as well.

One of the largest organization in the field of credit guarantee is the European association of guarantee institutions (known as AECM). AECM includes 48 member organizations, operating in 30 European countries (23 EU countries in addition to Azerbaijan, Bosnia, Russia, Herzegovina, Kosovo, Serbia, and Turkey). Its members are mutual, private sector guarantee schemes as well as public institutions. These are either guarantee funds or Development banks with a guarantee division. Their mission is to provide loan guarantees for SMEs, which cannot provide sufficient bankable collateral but have an economically sound project. AECM member organizations had in 2017 a total guarantee volume in the portfolio of over EUR 125.6 billion.

In order to measure the efficiency of its members, AECM has wide-ranging publications, statistics and studies. One of the indicators is to measure the ratio of new guarantees to outstanding guarantees each year.

For example, for AECM members on average, the ratio of new activity decreased between 2010 and 2013. Also in numbers, the ratio trended downward for the three years between 2010 and 2013. The ratio of AECM members varies between $19 \%$ and $133 \%$ for new activity in volume and between 0.3 and $104 \%$ in number. The average ratio of new activity for JLGC in number is $52 \%$, and it is around $132 \%$ for new activity in volume for the period 2005-2019. This means the ratios are not very different from AECM's regional indicators. Figure 4 shows the trend of the ratio of new activity for JLGC for the last fifteen years.

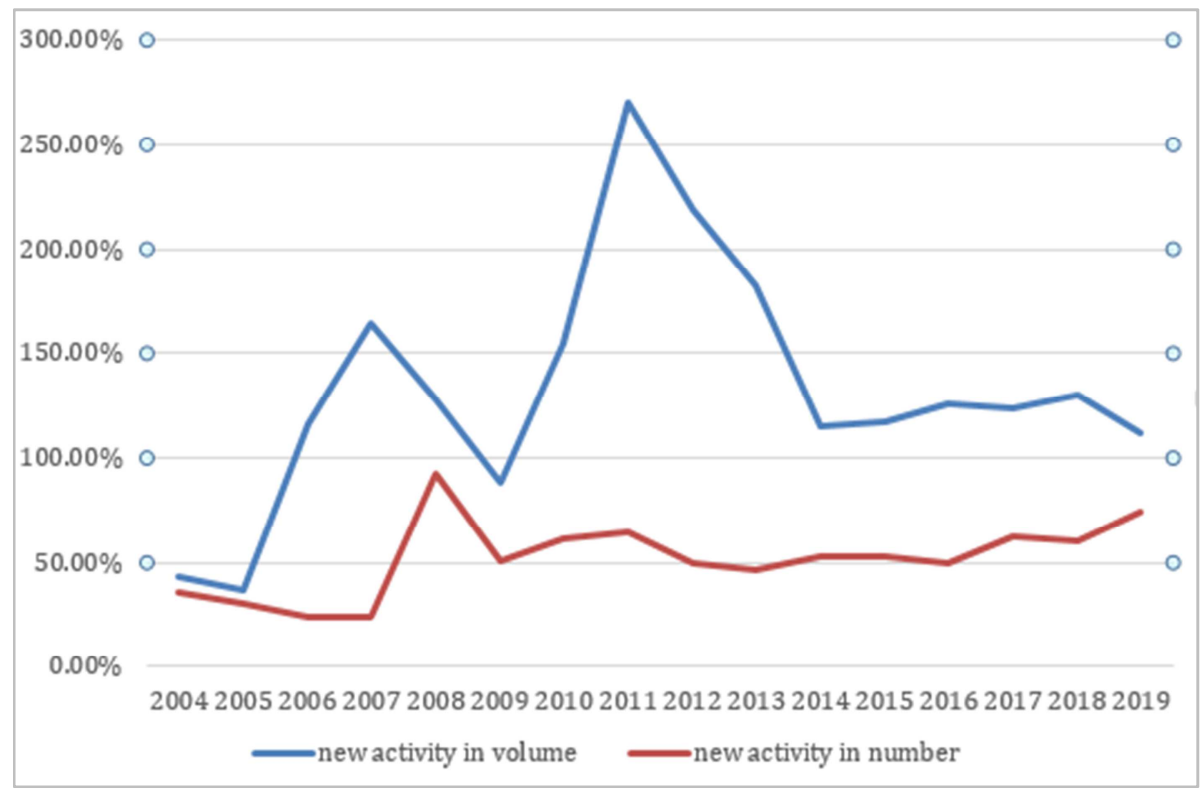

Figure 4. New activity ratio for JLGC in both volume and number.

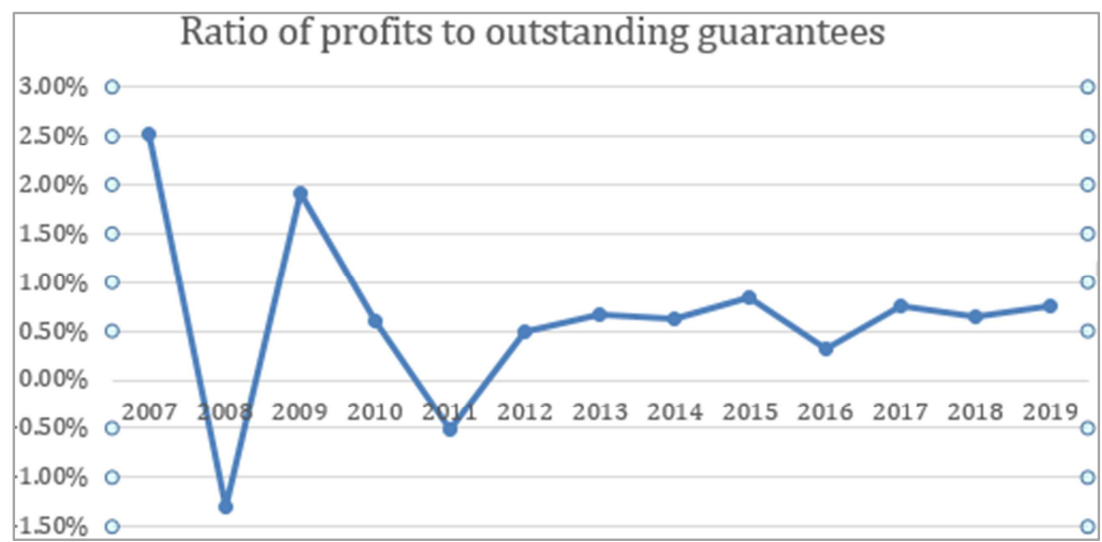

Figure 5. The ratio of JLGC profits to outstanding guarantees. 
To evaluate the performance of JLGC, we use the ratio of profits to outstanding guarantees. This gives a measure of profit per Dinar of outstanding guarantees. In figure 5 we can see that profits per JD is increasing yearly and it was varying mainly during the period after the financial crisis, but then it stabilized since 2012. It is noticed that during the financial crisis of 2008, JLGC suffered a loss but it is very interesting that it was able to recover its losses. From this, we can conclude that JLGC can continue and grow not only as a tool of economic stabilization.

\subsubsection{Benefits of JLGC Programs to SMEs and the Economy}

As shown in figure 6, the credit to SMEs to total banking credit to the private sector is only about $10 \%$ which is considered small, especially relative to the importance of such sector. The main rationality behind credit guarantee programs is to help SMEs overcome the difficulty to get access to finance from banks.

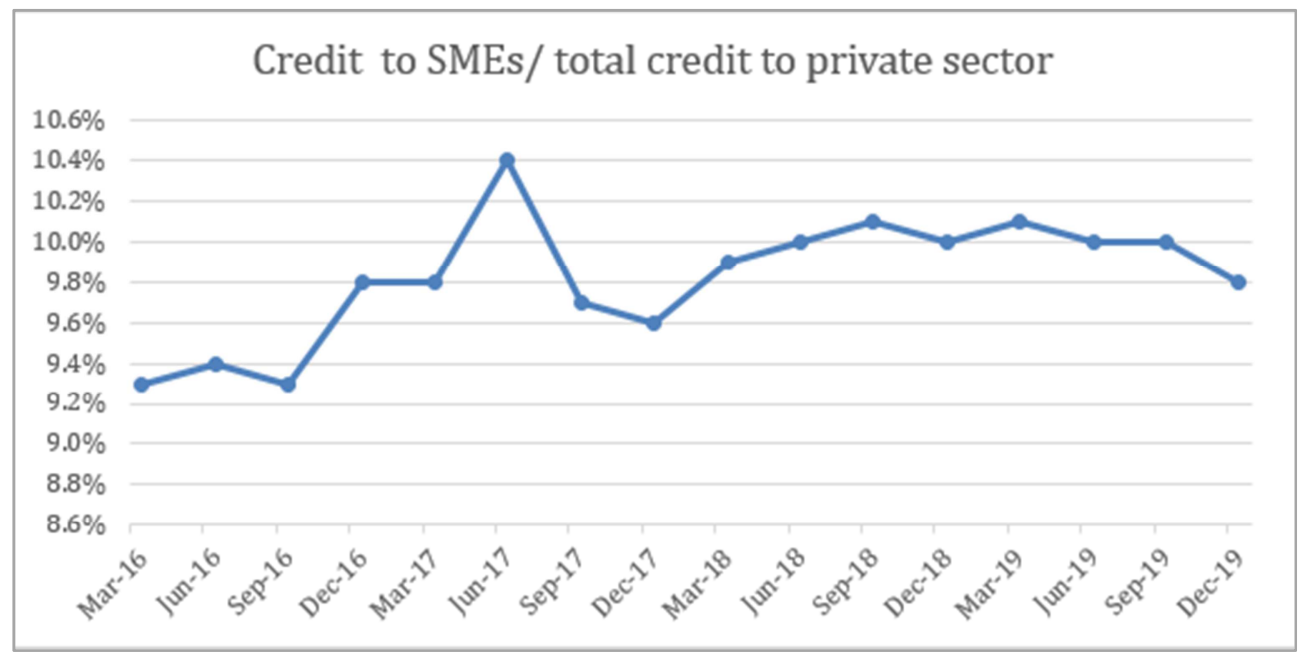

Figure 6. Credit to SME/ total credit to private sector.

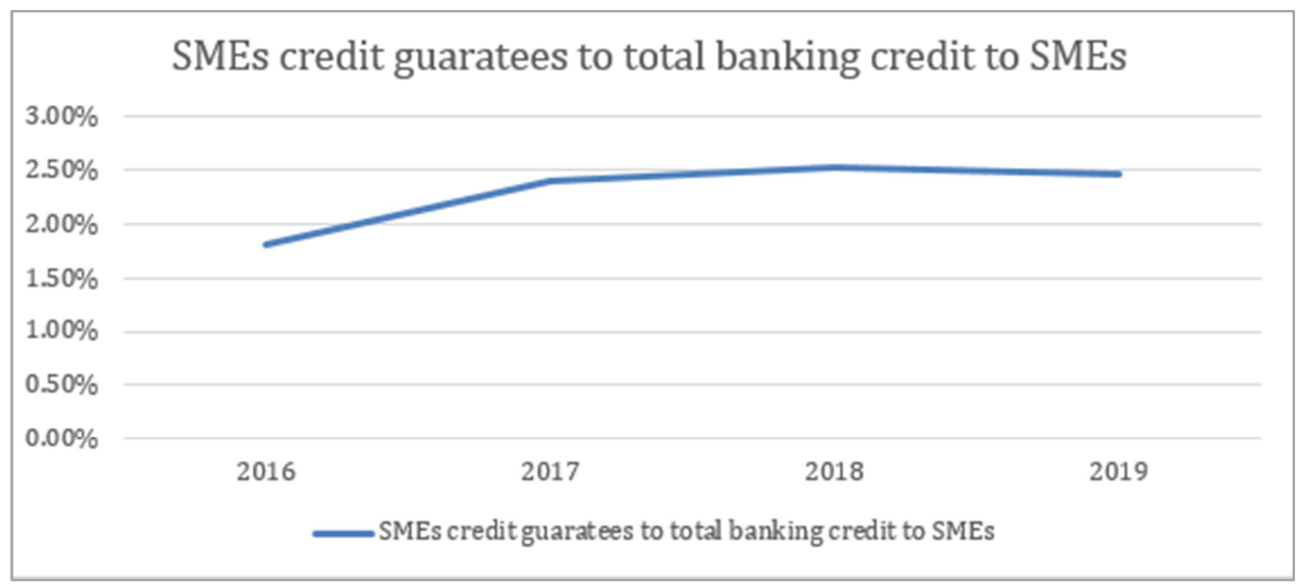

Figure 7. SMEs credit gurantee to total credit to SMEs.

If we link the credit guarantees and total banking credit to small and medium enterprises, over the last years, we can conclude that around $2.5 \%$ from the loans to SMEs in the banking system were guaranteed by JLGC and its trend increased. (See figure 7)

Besides helping SMEs by increasing their access to finance, JLGC has a relatively low fee which helps SMEs to reduce their borrowing costs and enhance their competitiveness. The ratio of guarantees to total banking credit should be higher to maximize these benefits. We argue that more efforts are needed to stimulate the credit guarantee system In Jordan.

In addition to JLGC's role in supporting SMEs, it has a significant role in stabilizing and motivating the growth of the economy. AECM uses the ratio of outstanding guarantees to GDP to assess the importance of the credit guarantee system and its contribution to the economy. The ratio of AECM members for the period between 2007 and 2012 was $0.6 \%$, according to their statistics. If we calculate the ratio for JLGC's outstanding guarantees, we find it contributed up to $0.30 \%$ on average for the last 10 years. Moreover, its trend is shown in figure 8 , it decreased sharply in the years following the financial crisis, but it has again steadily increased since 2014. This may lead us to conclude that JLGC must play a better role in helping to stabilize the economy during crises as 
in AECM reports they indicate that European countries used financial crisis.

credit guarantee schemes as a tool to avoid and overcome the

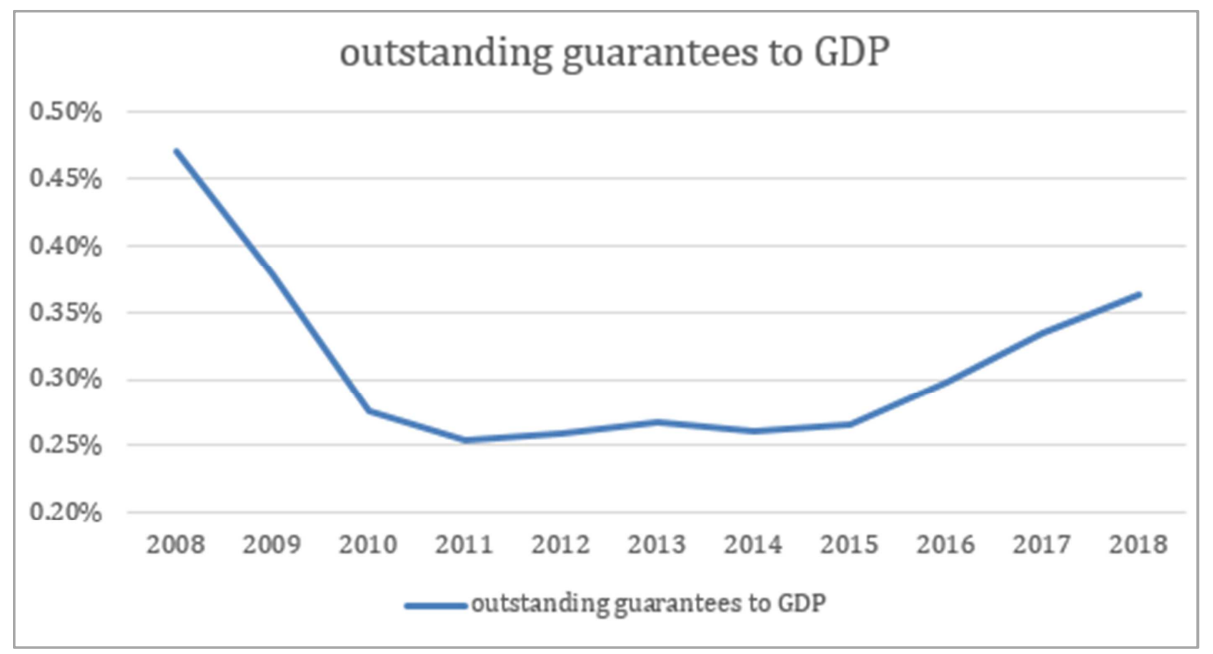

Figure 8. outstanding gurantees to GDP.

\section{The National Program for Finance and Loan Guarantee to Encounter COVID-19}

It worth to mentioning that the Jordanian government used credit guarantee as a tool to deal with the COVID-19 crisis. In April 2020, CBJ launched a new special program with JLGC to motivate SMEs lending so they can get their financing needs to pay salaries, finance their operating and working capital, sustainability and development needs.

Target groups are:

Companies that qualify for the program are required to employ fewer than 200 workers, and their total assets or sales must be less than 5 million Jordanian Dinars.

Loans provided by banks to professionals, craftsmen, individual institutions, small and medium-sized companies and for the listed sectors below according to the following ceilings for each beneficiary of the program by sector:

Table 5. Ceilings for each sector for covid-19 program.

\begin{tabular}{ll}
\hline Sector & Ceiling (JD) \\
\hline The government's work on the development of the health sector has been & 20,000 Dinars \\
Retail & 50,000 Dinars \\
Wholesale trade & 250,000 Dinars \\
Tourism services excluding hotels & 250,000 Dinars \\
Hotels & 1 million Dinars \\
IT & 500,000 Dinars \\
Manufacturing, including agricultural-based industries & 1 million Dinars \\
Transport & 1 million Dinars \\
Health facilities and services excluding hospitals & 250,000 Dinars \\
Hospitals & 1 million Dinars \\
Education sector & 500,000 Dinars \\
\hline
\end{tabular}

1) The program's size is JD 500 million distributed to all banks.

2) The program covers $85 \%$ of the value of any loan/financing on the date of the default plus interests of six months.

3) The program will be suspended with any bank if the default rate on loans/financing guaranteed under the program reaches $15 \%$, including the net amount of compensation paid to the bank for the last 12 months.

\subsection{How the Program Works}

Banks receive requests for financing from customers, conduct credit audits and take the necessary professional care in evaluating applications in accordance with their business procedures and credit policies and authorize banks to provide financing/loans within the program up to 250 thousand Dinars per loan. Without referring to the Jordanian company to guarantee loans, provide advance information through the company while requiring it to obtain prior approval from the Jordanian company to guarantee loans for more than that.

\subsection{Corona Program Actual Performance}

On 16 July $2020 \mathrm{CBJ}$ and JLGC announced the results of the program:

1) 3942 credit applications were approved under this program with a value of 380.8 million Dinars.

2) The average value per loan was $96,600 \mathrm{JD}$.

3) The most significant volume and number of loans 
granted was in the trading sector with 1,795 loans granted with the value of 139.1 million Dinars, which is $36.5 \%$ of all sector loans guarantees. Then the industrial sector with 431 loans granted with the value of 75.4 million JDs (19.8\% of all loans guarantees)

4) It is noticed that $43 \%$ of the guaranteed loans approved-with a total value of 163 million-were to pay salaries and those served 79 thousand workers.

5) If we consider this 380.8 million new guarantees, the new ratio of outstanding guarantees to GDP will jump to more than $1.5 \%$ (which is higher than AECM members' average).

\section{Conclusions}

After viewing the international experience with public credit guarantee schemes, which have gained popularity over the last decades, the evidence reviewed suggests that the Jordanian government represented by the Central Bank of Jordan and in cooperation with the Jordan Loan Guarantee corporation are paying attention to loan guarantee schemes as a policy of intervention and their use as a tool to stimulate the economy and support small and medium enterprises by increasing their access to finance and at a lower cost.

The actual results indicate that the new guarantees approved annually and outstanding guarantees are both increasing. Also, the calculated New Activity Index is also trending upward and is located within the European Association of Guarantee Institutions Members' average.

The rate of profits to outstanding guarantees is also increasing, which means that the Jordanian Loan Guarantee Company can work, develop and achieve profits in addition to its development goal. The analysis shows that only about $2.5 \%$ of the loans to SMEs are guaranteed which needs to be raised so support these companies better.

In terms of the impact on the economy, the ratio of guarantees to GDP was relatively small compared to international indicators. It, therefore, must be improved with more considerable attention to these programs. Note that the government's recent initiative in the National Program for Finance and Loan Guarantee to encounter Corona is working on the allocation of sufficient amounts to support companies, which brings up this percentage to about $1.5 \%$, which is an excellent level.

The paper concluded the positive impact of JLGC on the Jordanian economy, but it stressed that more emphasis on the guarantee system is needed to achieve policy goals. This needs cooperation between all parties of the banking system, CBJ, and JLGC. In addition, more in-depth analysis will be fruitful.

\section{References}

[1] Chowdhury, S. R., 2011. "Impact of the global crisis on small and medium enterprises. Global Business Review, 12 (3), 377-399.

[2] Levine, R. 2005. "Finance and growth: Theory and evidence. In Handbook of economic growth, (Eds), P. Aghion \& S. Durlauf,
Amsterdam: North-Holland Elsevier Publishers.

[3] Narteh, B., 2013. "SME bank selection and patronage behaviour in the Ghanaian banking industry. Management Research Review, 36 (11), 1061-1080.

[4] OECD (2014a). "Financing SMEs and Entrepreneurs: An OECD Scoreboard, OECD Publishing, Paris.

[5] Beck, T., A. Demirgüç-Kunt, and P. Honohan, 2008. "Finance for All? Policies and Pitfalls in Expanding Access". World Bank, Washington, DC.

[6] Chavis, L., Klapper, L. and Love, I. 2010. "The Impact of the Business Environment on Young firm financing". Policy research working paper. The World Bank.

[7] Basley, J., 1994. "Marketing tactics of selected small firms in East London CBD area" South Africa University.

[8] OECD, 2013. "SME and Entrepreneurship Financing: The Role of Credit Guarantee Schemes and Mutual Guarantee Societies in Supporting Finance for Small and Medium-sized Enterprises". OECD, Paris.

[9] Zecchini, Salvatore and Ventura, Marco 2009. "The Impact of Public Guarantees on Credit to SMEs". Small Business Economics, Vol. 32, No. 2, pp. 191-206.

[10] Mendizabal, A., Zubia, M., Lertxundi, A. 2013. "Degree of guarantee rationing and banking relationship of Spanish SME". Procedia Social and Behavioral Sciences 109 (2014) 753-757 http://dx.doi.org/10.1016/j.sbspro.2013.12.539

[11] Levitzky, J., Ranga, N. P., 1989. "Credit Guarantee Schemes for Small and Medium Enterprises". World Bank technical paper number 58 .

[12] Levitzky, J., 1997. "Best Practice in Credit Guarantee Schemes". The Financier-Analyses of Capital and Money Market Transaction 4, 86-94.

[13] Beck, T., 2010. "SME Finance: What Have We Learned and What Do We Need to Learn?" The Financial Development Report: 187-195.

[14] Roodman, D., \& Qureshi, U. (2006): "Microfinance as a business". Center for Global Development.

[15] Beck, T., L. F. Klapper, and J. C. Mendoza. 2010. "The Typology of Partial Credit Guarantee Funds around the World". Journal of Financial Stability 6, 10-25.

[16] Kang, J., \& Heshmati, A., 2008. "Effect of credit guarantee policy on survival and performance of SMEs in the Republic of Korea”. Small Business Economics, 31 (4), 445-462. http://dx.doi.org/10.1007/s11187-007-9049-y

[17] Janda, K., MichalikovaI, E., Skuhrovec, J. 2012 "Credit Support for Export: Econometric Evidence from the Czech Republic" IES Working Paper 12/2012. IES FSV. Charles University. http://dx.doi.org/10.2139/ssrn.2061868

[18] Riding, A. L., \& Haines. (2001): Loan guarantees: costs of default and benefits to small firms. Journal of Business Venturing, 16 (6), 595-612.

[19] Lawrence Oparinde, Taiwo Amos, Michael Adeseluka. 2017, "Influence of agricultural credit guarantee scheme fund (ACGSF) in fishery development in Nigeria" Scientific Papers Series Management, Economic Engineering in Agriculture and Rural Development, Vol. 17 Issue 1. 
[20] Akerele Dare, Ashaolu Olumuyiwa, Sanusi Rahman and Egbetade Adedolapo, 2017, "Analysis of partial effects of agricultural credit guarantee scheme fund outputs in Nigeria's agricultural subsectors”. Sarhad journal of Agriculture, vol 33, No. 4: 630-638.

[21] Pombo P., Herrero A. 2003, "Los Sistemas de Garantia para la Micro y la Pyme en una Economia Globalizada, Cyberlibro.

[22] Carlos Gozzi, \& Schmukler, Sergio, 2016. "Public Credit Guarantees and Access to Finance," The Warwick Economics Research Paper Series (TWERPS) 1122, University of Warwick, Department of Economics.

[23] OECD (2017), "Evaluating Publicly Supported Credit
Guarantee Programmes for SMEs", www.oecd.org/finance/Evaluating-Publicly-Supported-CreditGuarantee-Programmes-for-SMEs.pdf

[24] Shim, I. 2006. "Corporate credit guarantees in Asia." BIS Quarterly Review, 1-14 Stephens, M., 1999. The Changing Role of Export Credit Agencies. International Monetary Fund, Washington, DC.

[25] Dang T. Binhi, 2015. The economic impact of credit Guarantee system-Hungarian case study, Club if economics in Miskolc, Vol. 11 pp 11-24.

[26] Abushanab, S., 2015. Small and medium enterprises role in solving the poverty problem and unemployment. DSpace at $\mathrm{Al}$ al-Bayt University. 